\title{
FILM DOKUMENTER ANAK AGUNG PANDJI TISNA "JEJAK PUJANGGA PIONIR LOVINA"
}

\author{
Istacy Rosree Octivany Robin1, I Gede Partha Sindu2 , I Gede Mahendra Darmawiguna3
Program Studi Pendidikan Teknik Informatika, Universitas Pendidikan Ganesha
Singaraja, Indonesia
e-mail: napiror1a@gmail.com ${ }^{1}$, mahendra.darmawiguna@undiksha.ac.id ${ }^{2}$,
partha.sindhu@undiksha.ac.id ${ }^{3}$

\begin{abstract}
Abstrak
Penelitian ini bertujuan (1) merancang dan mengimplementasikan hasil rancangan Film Dokumenter Anak Agung Pandji Tisna (2) mengetahui respon kalangan masyarakat terhadap hasil film dokumenter Anak Agung Pandji Tisna. Jenis penelitian yang digunakan adalah penelitian dan pengembangan dengan model cyclic strategy. Model cyclic strategy terdiri dari tahap brief, tahap 1 (pengumpulan data dan analisis), tahap 2 (praproduksi), evaluasi 1, tahap 3 (produksi dan pasca produksi), evaluasi 2, tahap 4 (burning, desain poster, dan desain DVD), outcome dan uji respon penonton. Film ini diimplementasikan menggunakan Adobe Premiere Pro Cs6 sebagai software editing video. Melalui Film Dokumenter Anak Agung Pandji Tisna masyarakat diharapkan dapat meluruskan persepsi tentang Lovina dan mengenal Anak Agung Pandji Tisna. Hasil penelitian menunjukkan respon masyarakat terhadap film dokumenter ini sebesar $91,2 \%$ dengan indeks pencapaian sangat baik. Jadi, dapat disimpulkan bahwa Film Anak Agung Pandji Tisna "Jejak Pujangga Pionir Lovina" berhasil dan layak untuk dipublikasikan.
\end{abstract}

Kata kunci: lovina, film dokumenter, cyclic strategy

\begin{abstract}
This study aims to (1) design and implements the design Documentary Pandji Tisna (2) study the response of the community to the results of the documentary Pandji Tisna. This type of research is the research and development with the cyclic model strategy. Cyclic model strategy phase consists of brief, stage 1 (data collection and analysis), phase 2 (pre-production), the evaluation 1, stage 3 (production and postproduction), the evaluation 2, step 4 (burning, poster design, and design DVD), outcome and tests the public's response. The film is implemented using Adobe Premiere Pro CS6 as video editing software. Through Documentary Film Pandji Tisna community is expected to correct perceptions about Lovina and know Pandji Tisna. The results showed the public response to this documentary with an index of $91.2 \%$ is a very good achievement. Thus, it can be concluded that the film Pandji Tisna "Jejak Pujangga Pionir Lovina" successful and worthy to be published.
\end{abstract}

Keywords : Lovina, Documentary, cyclic strategy

\section{PENDAHULUAN}

Kemajuan pariwisata di Bali khususnya kabupaten Buleleng, yang perkembangannya dapat kita lihat sampai saat ini, tidak terjadi serta merta begitu saja tanpa perjuangan para pendahulu kita. Salah satu tokoh pelopor pariwisata di Buleleng ialah Anak Agung Pandji Tisna yang memang telah banyak berjasa dalam pembangunan pariwisata. Anak Agung
Pandji Tisna merupakan 'penemu' kawasan Pariwisata Lovina. Nama kawasan ini pun merupakan ciptaannya. Dengan demikian, Lovina sebagai salah satu kawasan pariwisata yang terkenal di Bali, tidak bisa dilepaskan dari eksistensi sang Pujangga Pionir Lovina [1] .

Stimulus gagasan konsep yang dikembangkan Pandji Tisna tersebut mendorong berkembangnya bisnis 
perhotelan di Buleleng Timur dan Buleleng Barat. Mulai tahun 1970-an, kalangan investor tertarik untuk membangun akomodasi (hotel, homestay, dan villa) di areal sekitar Guest House milik beliau, yakni "Lovina". Guest House "Lovina" menjadi terkenal berkat publikasi Pandji Tisna sendiri dan kalangan sahabatsahabatnya dari dalam ataupun luar negeri yang berkunjung bahkan menginap di Guest House dan hotel milik Pandji Tisna.

Kawasan pariwisata Lovina yang dicetuskan Pandji Tisna menjadi daya tarik tersendiri bagi kedatangan wisatawan mancanegara. Tidak hanya eksis sementara, namun hingga tahun 1990-an Lovina tidak pernah sepi pengunjung. Namun seiring berjalannya waktu, eksistensi Pandji Tisna di Buleleng mulai menurun bahkan banyak yang tidak mengenal siapa beliau. Dilansir dari website www.tatkala.co melalui tulisannya yang berjudul Mengenang Pandji Tisna, Pujangga Besar yang Sepi dari Upacara Peringatan Made Adnyana Ole mengungkapkan "Orang-orang di Bali praktis mengenal Pandji Tisna hanya dalam buku-buku pelajaran sastra di sekolah menengah. Tentu saja, karena Bali sendiri sepertinya tak begitu bangga memiliki Pandji Tisna" [2].

Pada masa sekarang ini multimedia telah dapat mengembangkan proses penyampaian informasi menjadi lebih dinamis dan efektif. Multimedia merupakan perpaduan antara kata multi yang berarti banyak atau bermacam-macam dan media yaitu sesuatu yang digunakan untuk menyampaikan. Salah satu produk multimedia yang mampu menyampaikan hal tentang Anak Agung Pandji Tisna dengan lebih menarik adalah film dokumenter. Pada dasarnya, film dokumenter merepresentasikan kenyataan. Dimana di dalam film ini menampilkan kembali fakta yang ada dalam kehidupan, wawancara dengan berbagai narasumber yang dapat dipercaya, dan narasi untuk lebih menegaskan lagi apa yang akan disampaikan.

Selain itu, karena unsur yang diutamakan adalah sosok Anak Agung Pandji Tisna yang telah tiada, maka dengan membuat film akan memberikan kesan yang lebih hidup dan nyata. Untuk itu peneliti menawarkan solusi dengan pembuatan "Film Dokumenter Anak Agung Pandji Tisna (Jejak Pujangga Pionir Lovina)".

Film dokumenter berhubungan dengan orang-orang, tokoh, peristiwa, dan lokasi yang nyata. Film dokumenter tidak menciptakan suatu peristiwa atau kejadian namun merekam peristiwa yang nyata dan sungguh-sungguh terjadi atau otentik [3]

Penelitian film dokumenter sudah pernah dilakukan oleh peneliti lain, salah satunya yaitu penelitian berjudul Film Dokumenter Anjing Bali Tuan Rumah Sejuta Kisah mengangkat kontroversi tentang anjing Bali di masyarakat [4]. Film ini memperoleh hasil dari uji ahli isi dan uji ahli media yang dikategorikan ke dalam pencapaian sangat baik. Berdasarkan hasil uji respon film dokumenter Anjing Bali, tuan rumah sejuta kisah terhadap 30 responden yang berasal dari masyarakat terutama generasi muda, diperoleh persentase keseluruhan sebanyak 89,20 \%. Hasil yang diperoleh ini dikategorikan ke dalam pencapaian baik. Begitu pula dengan penelitian Film Dokumenter Permainan Tradisional "Magandu": Sebuah Tardisi sebagai Warisan Budaya Sistem Subak Bali [5]. Film ini berisi tentang permainan tradisional magandu yang dapat dimanfaatkan sebagai alat bantu dalam bentuk dokumentasi digital untuk mensosialisasikan permainan tradisional magandu.

Berdasarkan analisis terhadap 30 orang responden yang berasal dari kalangan siswa dan guru Sekolah Dasar dinyatakan bahwa film dokumenter permainan tradisional "Magandu" mendapatkan total sebesar $93,73 \%$ yang masuk dalam kategori "sangat baik".

Berdasarkan latar belakang diatas Film Dokumenter Anak Agung Pandji Tisna "Jejak

Pujangga Pionir Lovina" diharapkan akan menumbuhkan inspirasi, semangat, dan motivasi generasi muda untuk meneruskan perjuangan didalam melanjutkan pembangunan pariwisata dan kebudayaan. 
Film ini juga dapat dijadikan inventaris dokumentasi digital tentang jejak Pandji Tisna dalam bidang kebudayaan dan pariwisata di Kabupaten Buleleng dan dapat membantu pemerintah untuk melestarikan, memperkenalkan, dan mendokumentasikan warisan budaya yang ada di daerah.

\section{METODE}

Metode penelitian yang digunakan dalam Film Dokumenter Anak Agung Pandji Tisna "Jejak Pujangga Pionir Lovina" adalah metode pengembangan dengan model cyclic strategy. Cyclic strategy merupakan sebuah metode yang ada kalanya suatu tahap perlu diulang kembali sebelum tahap berikutnya dilanjutkan [6].

Berikut ini merupakan tahapan yang terdapat pada model cyclic strategy:
Riset awal dilakukan setelah ide yang diajukan diterima. Peneliti mencari informasi yang berguna sebagai bahan untuk pembuatan film.

\section{B. Tahap I ( Pengumpulan Data dan} Analisis)

Hal yang harus dilakukan pada Tahap 1 adalah pengumpulan data dan analisis film.

a. Pengumpulan data

Pengumpulan data dilakukan untuk mendukung proses penelitian. Dalam fase ini, peneliti melakukan pengumpulan data dengan cara observasi, wawancara, penyebaran angket, studi pustaka dan dokumentasi.

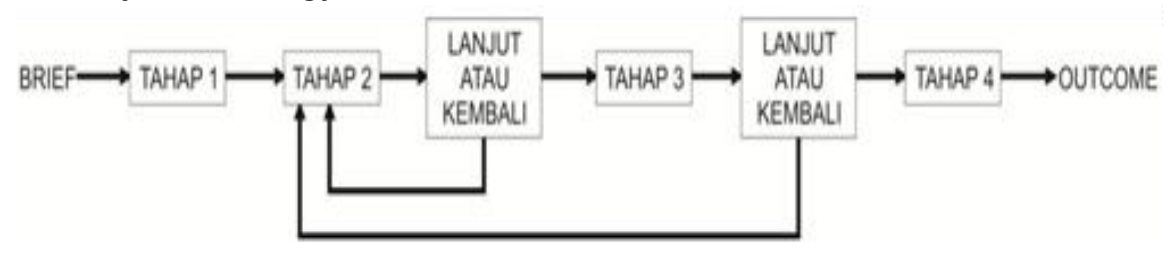

Gambar 3.1 Model Cyclic Strategy [6]

Setiap tahapan yang ada pada model cyclic strategy memiliki keterkaitan satu sama lain sehingga semua tahap harus terlewati secara terstruktur. Rincian tahapan dalam model cyclic strategy yaitu:

\section{A. Brief}

Brief merupakan tahap awal dalam model cyclic strategy dimana pada tahapan ini terdapat 3 fase, yaitu:

a. Pemantapan Ide

Ide yang telah dipikirkan peneliti lebih dipadatkan sehingga pada saat penawaran ide dapat diterima dengan baik dan dapat dipertanggung jawabkan.

b. Penawaran Ide

$$
\text { Ketika ide film sudah }
$$
dimantapkan, peneliti mulai melakukan penawaran kepada pihak Juruan Pendidikan Teknik Informatika melalui Ketua Jurusan. Judul penelitian yang diajukan adalah Film Dokumenter Anak Agung Pandji Tisna "Jejak Pujangga Pionir Lovina".

c. Riset Awal b. Analisis

Analisis yang dilakukan peneliti yaitu analisis kebutuhan film, analisis SWOT (Strenght, Weakness, Opportunity, Threat), dan analisis STP (Segmentation, Targeting, Positioning).

C. Tahap II ( Pra Produksi)

Pembuatan ide cerita, sinopsis, skenario dan storyboard dilakukan pada tahap 2 yang disebut tahap pra produksi. Hal tersebut dilakukan untuk dijadikan acuan dalam tahap produksi yaitu pengambilan gambar.

D. Evaluasi Tahap I

Tahap 1 dan tahap 2 yang telah dilakukan diperiksa kembali dalam evaluasi 1 sebelum dilanjutkan ke tahap berikutnya.

E. Tahap III ( Produksi dan Pasca

Produksi)

Pada tahap 3 dilakukan proses produksi dan pasca produksi. Tahap produksi sudah mulai dilakukan pengambilan gambar yang sesuai 
dengan naskah yang telah dibuat lalu dilanjutkan ke proses pasca produksi.

F. Evaluasi Tahap II

Evaluasi 2 dilakukan untuk memeriksa hasil kerja tahap 3.

G. Tahap 4 ( Burning and Design)

Setelah semua tahap diselesaikan akan dilanjutkan ke tahap 4 yaitu, tahapan burning dan desain.

H. Outcome / Publishing

Tahap terakhir yaitu outcome dimana setelah tahap burning dan desain selesai dilaksanakan film dipublikasikan.

\section{HASIL DAN PEMBAHASAN}

\section{A. Brief}

Tahap brief merupakan tahap pertama dalam metode cyclic strategy. Berikut merupakan hasil setiap fase pada tahap Brief, yaitu:

1. Hasil Pemantapan Ide

Pada pemantapan ide, peneliti melakukan observasi awal untuk memantapkan ide seperti mencari informasi tentang Anak Agung Pandji Tisna melalui berbagai media hingga terjun langsung ke lapangan untuk menganalisis pengetahuan masyarakat umum tentang Anak Agung Pandji Tisna. Setelah itu peneliti memantapkan ide menjadi sebuah topik yaitu keterkaitan antara kawasan pariwisata Lovina dan Anak Agung Pandji Tisna.

Melihat banyaknya kesalahan persepsi masyarakat Buleleng tentang Lovina baik dari segi batas wilayah dan sejarah serta nama Lovina itu sendiri, peneliti mempertegas topik dengan menawarkan solusi pembuatan Film Dokumenter Anak Agung Pandji Tisna "Jejak Pujangga Pionir Lovina".

2. Hasil Penawaran Ide.

Penawaran Ide atau pengajuan ide dilakukan kepada pihak yang akan bertanggung jawab dalam pembuatan Film Dokumenter Anak Agung Pandji Tisna "Jejak Pujangga Pionir Lovina". Dalam penawaran ide, peneliti memperkuat gagasan dengan beberapa komponen dalam bentuk teks berisi tentang permasalahan yang terjadi terkait Anak Agung Pandji Tisna dan kawasan pariwisata Lovina. Pada fase ini, pengajuan ide/topik telah disetujui pada 24 Nopember 2017.

3. Hasil Riset Awal

Setelah ide diterima, peneliti melakukan riset awal yang berkaitan dengan film dokumenter, Anak Agung Pandji Tisna dan Lovina melalui buku, penelitian yang pernah dilakukan dan film dokumenter yang ada di youtube untuk mendapatkan inspirasi dalam pengemasan film.

Penelitian yang pernah dilakukan didapatkan melalui jurnal terkait film dokumenter. Pada beberapa jurnal yang dijadikan acuan, peneliti mendapat informasi tentang metode yang cocok digunakan dalam pembuatan film, pengujian serta teoriteori tentang film dokumenter.

Untuk informasi tentang Anak Agung Pandji Tisna dan Lovina, peneliti langsung mendatangi salah satu keluarga Anak Agung Pandji Tisna yaitu cucu kandung belliau. Selain itu peneliti juga mencari informasi tambahan melalui beberapa novel yang ditulis Anak Agung Pandji Tisna.

B. Hasil Tahap I (Pengumpulan Data dan Analisis)

1. Hasil Pengumpulan Data

a. Hasil Observasi

Peneliti melakukan observasi dengan mendatangi Museum yang dibangun langsung oleh cucu kandung beliau. Kemudian peneliti juga mendatangi pemilik Lovina Beach Hotel dimana pada hotel tersebut terdapat sebuah patung Anak Agung Pandji Tisna yang sengaja dibuat untuk menghormati beliau. Selain itu, peneliti juga berziarah ke makam beliau yang ada di daerah Temukus Desa Kaliasem.

b. Hasil Wawancara

Peneliti melakukan wawancara dengan beberapa narasumber yaitu Anak Agung Ngurah Brawida sebagai cucu kandung pertama Anak Agung Pandji Tisna yaitu 
tentang Anak Agung Pandji Tisna, keadaaan Lovina di tahun 1953 dan arti kata Lovina.

Kemudian pemilik Lovina Beach Hotel yaitu Anak Agung Ngurah Sentanu, peneliti mewawancarai beliau terkait perkembangan pariwisata Lovina dari tahun 1953 hingga saat ini.

\section{c. Studi Literatur}

Peneliti melakukan studi literatur untuk mendapatkan referensi berupa teori yang dapat digunakan dalam penelitian. Studi literatur yang dilakukan oleh peneliti bersumber dari buku dan jurnal. Buku yang digunakan oleh peneliti yaitu buku tentang film dokumenter dan teknik pengambilan gambar dalam pembuatan film, salah satu buku yang digunakan oleh peneliti yaitu buku berjudul Dasar-dasar Produksi Televisi: Produksi Berita, Feature, Laporan Investigasi, Dokumenter dan Tahapan Editing karya Fachruddin. Sedangkan jurnal yang digunakan oleh peneliti yaitu jurnal pembuatan film dokumenter yang memuat teknik-teknik pengambilan gambar, metode penelitian serta teori dalam film dokumenter.

\section{d. Penyebaran Angket}

Penyebaran angket dilakukan untuk mengetahui dan menganalisis pengetahuan masyarakat umum tentang Anak Agung Pandji Tisna dan Lovina. Peneliti melakukan penyebaran angket di wilayah Kabupaten Buleleng dengan melibatkan 30 responden.

e. Dokumentasi

Peneliti melakukan dokumentasi pada beberapa tahap penelitian, seperti saat wawancara, penyebaran angket, pengambilan gambar, serta editing. Selain itu, peneliti juga meminta beberapa dokumentasi tambahan dari keluarga Anak Agung Pandji Tisna untuk dijadikan referensi ataupun bagian dari film.

\section{Analisis}

Berdasarkan hasil pengumpulan data yang di dapatkan kemudian dilakukan beberapa tahapan analisis sebagai berikut:

a. Analisis Talent

Pada Film Dokumenter ini, peneliti melibatkan beberapa talent sebagai narasumber. Talent dalam film ini ada 2 jenis yaitu Narasumber dan Aktor.

b. Analisis Lokasi

Film dokumenter Anak Agung Pandji Tisna menggunakan lokasi pengambilan gambar di beberapa tempat di daerah Lovina, seperti pantai Lovina, The Little Museum of Anak Agung Pandji Tisna, Lovina Beach Hotel serta Makam Anak Agung Pandji Tisna dan Puri Agung Singaraja.

c. Analisis Alat

Peralatan yang digunakan dalam pembuatan film dokumenter Anak Agung Pandji Tisna adalah sebagai berikut: 2 buah DSLR Canon 60D, 3 buah tripod, 1 buah microphone DSLR (external), 1 buah stabilizer, 1 buah lampu Led, 1 buah PC Komputer.

d. Analisis Crew

Crew film dalam pembuatan film dokumenter Anak Agung Pandji Tisna terdiri dari :

- Produser

- Penulis Skenario

- Sutradara

- Kameramen 1

- Kameramen 2

- Kameramen 3

- Editor

- Penata Musik

e. Analisis SWOT

Berikut merupakan hasil analisa SWOT dari film dokumenter Anak Agung Pandji Tisna Jejak Pujangga Pionir Lovina.

- Strength: Ide cerita film ini memiliki keterkaitan yang sangat dekat dengan masyarakat buleleng pada khususnya. Film ini juga berisi subtitle Bahasa Inggris 
sehingga

mudah

mempromosikan sejarah Lovina yang kental pada wisatawan mancanegara yang berkunjung. Selain itu, dalam observasi Tidak sulit mengumpulkan informasi yang akurat.

- Weakness : Keterbatasan biaya, tenaga dan waktu dalam proses pembuatan film ini. Kemudian alat yang digunakan masih sederhana dan terbatas.

- Opportunity : Film dokumenter pertama yang mengangkat Anak Agung Pandji Tisna sebagai Tokoh. Kemudian, nanti film ini akan menjadi salah satu arsip di Dinas Kebudayaan dan Pariwisata khususnya di Kabupaten Buleleng.

- Threat : Setiap audience mempunyai persepsi atau pandangan tersendiri tentang menafsirkan cerita, sehingga terkadang apa yang ingin disampaikan belum tentu diterima dengan baik.

f. Analisis STP

Hasil analisa STP dari film dokumenter ini adalah:

- Segmentation: dapat ditujukan untuk seluruh indonesia bahkan seluruh dunia.

- Targeting: Film ini menyasar masyarakat luas dari usia 13 tahun keatas dari tingkat pendidikan SMP hingga umum.

- Postioning: Film dokumenter mengangkat salah satu tempat pariwisata yang penuh akan sejarah dan filosofi di Bali namun masyarakat awam khususnya generasi muda belum banyak mengetahui secara mendalam tentang sejarah Lovina dan Anak Agung Pandji Tisna.

C. Hasil Tahap II (Pra Produksi)

Pada Tahap 2 telah dilakukan proses pra produksi yang di awali dengan penentuan ide cerita film. Proses ini berguna untuk mengurangi kesalahan komunikasi pada saat pelaksanaan. Pada tahapan ini juga telah dilakukan pembuatan sinopsis, skenario dan juga storyboard film.

1. Ide Cerita

Ide merupakan suatu gagasan yang terancang dalam pikiran. Gagasan menyebabkan timbulnya konsep, yang merupakan dasar bagi segala macam pengetahuan.

\section{Sinopsis}

Sinopis merupakan gambaran cerita secara garis besar dari film yang dibuat. Sinopsis digunakan untuk membangun film dokumenter cenderung berubah disesuaikan dengan kondisi di lapangan.

3. Skenario

Skenario memuat rancangan cerita nyata yang akan di implementasikan. Selain itu, dalam sebuah skenario terdapat beberapa pembagian cerita yang disebut dengan scene yang berpengaruh terhadap jalan cerita pada skenario.

4. Storyboard

Storyboard merupakan gambaran sketsa dari cerita yang telah dirancang. Nantinya, storyboard akan menjadi pedoman saat tahap Produksi.

D. Hasil Evaluasi Tahap I

Tahap evaluasi 1 dilakukan untuk mengetahui kesiapan pada tahap 1 dan tahap 2 . Ada 2 pengujian yang dilakukan yaitu:

\section{Uji Ahli Isi Pra Produksi}

Berdasarkan data keseluruhan indikator penilaian dan persentase dari ahli isi yang dilakukan oleh cucu kandung Anak Agung Pandji Tisna dan pemilik Lovina Beach Hotel, maka dapat disimpulkan Film Dokumenter Anak Agung Pandji Tisna "Jejak Pujangga Pionir Lovina" dapat dikatakan kelayakan isi yang akan ditampilkan sudah sesuai dengan data dan fakta yang sebenarnya. Persentase diperoleh dari hasil masingmasing butir pernyataan, yaitu pada ahli 1 mendapatkan $100 \%$ dan ahli 2 mendapatkan $100 \%$, total keselururuhan yakni $100 \%$ dengan 
perhitungan nilai persentasi per jumlah ahli isi. Selain itu, ahli 2 juga memberikan komentar dan saran yaitu tema atau pokok penunjang dari film agar lebih diperjelas dalam film. Namun penulis sudah mengubah alur film dibeberapa bagian agar tema terlihat lebih jelas sehingga dapat dilanjutkan ke tahap produksi.

2. Uji Ahli Media Pra Produksi

Berdasarkan data keseluruhan indikator penilaian dan persentase dari uji ahli media yaitu divisi film dari komunitas Mahima dan aktivis dalam pembuatan dan perkembangan film di Bali khususnya di kabupaten Buleleng, maka dapat disimpulkan bahwa ide cerita, sinopsis, skenario, dan storyboard Film Dokumenter Anak Agung Pandji Tisna sudah baik. Pada ahli 1 mendapatkan $100 \%$ dan ahli 2 mendapatkan $\quad 100 \%$, total keselururuhan yakni $100 \%$ dengan perhitungan nilai persentasi per jumlah ahli media. Selain itu, ahli 1 memberikan komentar dan saran yaitu Ide dari film dokumenter ini bagus karena belum pernah ada yang membuatnya. Sedangkan komentar dan saran dari ahli 2 adalah penulis diminta untuk menyiapkan scene cadangan untuk menghindari kondisi yang tidak memungkinkan. Peneliti sudah menerima dan menerapkan saran yang diberikan sehingga, dapat film bisa dilanjutkan ke tahap produksi.

E. Hasil Tahap III ( Produksi dan Pasca Produksi)

\section{Produksi}

Tahap Produksi yang telah dilakukan dalam pembuatan film dokumenter ini adlaah shooting dan recording audio.

2. Pasca Produksi

a. Editing

Aplikasi yang digunakan pada saat editing yaitu:

- Adobe Premiere Pro CC 2017 (digunakan untuk softwere editing utama)
- Adobe After Effect Pro Cs6 (digunakan untuk editing effect tambahan)

- Adobe Audition Pro CC 2017 (digunakan untuk menipiskan noise)

Hardwere yang digunakan untuk mendukung editing yaitu sebuah komputer dengan spesifikasi:

- Processor : Intel Inside Core i7

- Harddisk : 1 TB

- Memory : 4 GB

b. Rendering

Hasil editing keseluruhan footage yang telah memiliki standar kualitas seragam akan menjalani proses rendering. Rencana properti metadata dari produk akhir Film Dokumenter Anak Agung Pandji Tisna "Jejak Pujangga Pionor Lovina”, yaitu:

Format : MP4 Video

Durasi : 20 Menit 08 Detik

Width : 1920 pixels

Height : 1080 pixels

Frame Rate:25 frames/second

F. Hasil Evaluasi Tahap II

Setelah tahap 3 selesai, dilakukan pengujian yang bertujuan untuk mengukur keterlaksanaan tahap 3 . Pengujian dilakukan dengan menggunakan kuisioner yang diisi oleh ahli isi dan ahli media.

1. Uji Ahli Isi Pasca Produksi

Persentase diperoleh dari hasil masing-masing butir pernyataan. Pada ahli 1 mendapatkan 100\% dan ahli 2 mendapatkan $100 \%$, total keselururuhan yakni $100 \%$ dengan perhitungan nilai persentasi per jumlah ahli isi , maka dapat disimpulkan Film Dokumenter Anak Agung Pandji Tisna "Jejak Pujangga Pionir Lovina" dapat dikatakan sudah sesuai dengan rancangan yang dibuat dan sesuai fakta yang sebenarnya. Selain itu juga tidak ada tambahan komentar atau pun saran dari kedua ahli, jadi film ini 
dapat dilanjutkan ke tahap berikutnya.

2. Uji Ahli Media Pasca Produksi

Persentase diperoleh dari hasil masing-masing butir pernyataan. Pada ahli 1 mendapatkan 100\% dan ahli 2 mendapatkan $77,78 \%$, total keselururuhan yakni $88,89 \%$ dengan perhitungan nilai persentasi per jumlah ahli media. Selain itu ahli 2 memberikan komentar untuk lebih menyesuaikan efek tampilan film dan mengurangi transisi dan peneliti telah melakukan revisi terkait hal tersebut. Jadi dapat disimpulkan bahwa Film Dokumenter Anak Agung Pandji Tisna "Jejak Pujangga Pionir Lovina" sudah memenuhi penilaian dari ahli media dan dapat dipublikasikan.

G. Hasil Tahap IV (Burning and Design)

Sebelum disebar luaskan, ditahap akhir film akan dikemas dalam bentuk DVD sesuai dengan format yang telah ditentukan. Selain itu, film juga akan di promosikan dalam bentuk poster.

\section{Burning}

Hasil pada tahap Burning yaitu dalam bentuk DVD dengan resolusi 1920 x 1080 dengan format H.264.

2. Design Cover dan Kepingan DVD

Berikut merupakan design cover DVD dan kepingan DVD yang telah dibuat sesuai rancangan:

a. Design Kepingan DVD

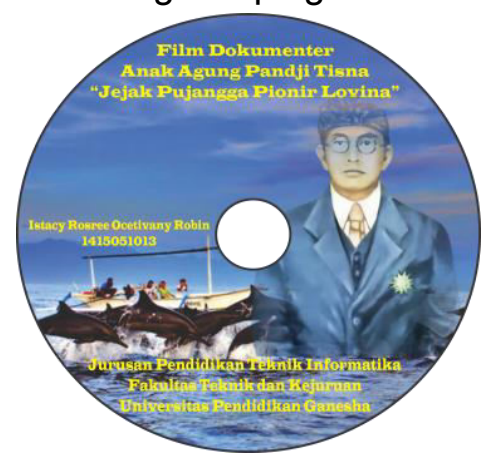

b. Design Cover DVD

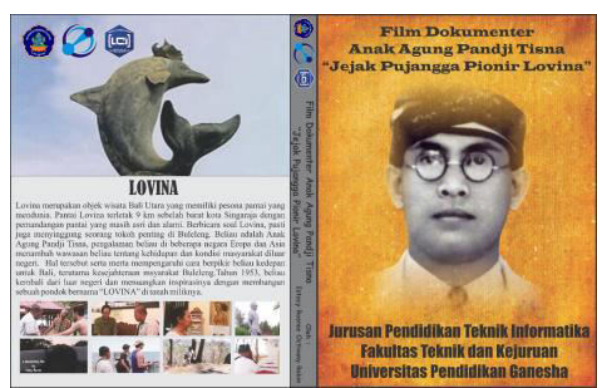

c. Design Poster

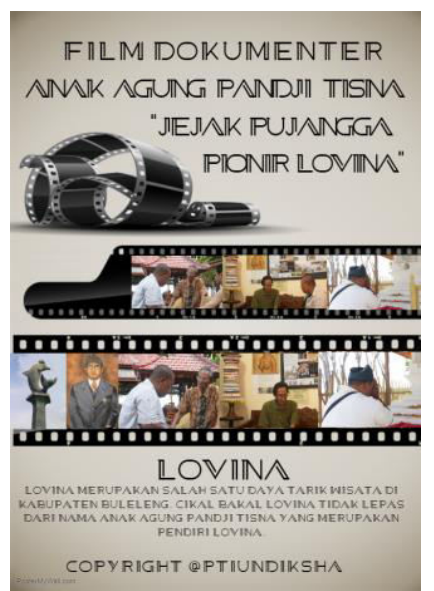

\section{H. Outcome / publishing}

Setelah film selesai dikemas, maka film siap untuk dipublikasikan sesuai dengan target yang telah ditentukan.

I. Uji Respon Penonton

Berdasarkan uji respon penonton yang telah dilakukan, didapatkan hasil persentase rata-rata sebesar $91,2 \%$ dengan tingkat pencapaian sangat baik. Dengan membandingkan data persentase keseluruhan subyek maka dapat disimpulkan bahwa Film Dokumenter Dokumenter Anak Agung Pandji Tisna "Jejak Pujangga Pionir Lovina" dapat dikatakan berhasil dan layak untuk dipublikasikan. Hasil perhitungan uji respon penonton dapat dilihat pada grafik berikut. 


\section{PEMBAHASAN}

Film Dokumenter Anak Agung Pandji Tisna "Jejak Pujangga Pionir Lovina" dalam proses pembuatan menerapkan Metode Cyclic Strategy. Cyclic Strategy merupakan sebuah metode yang ada kalanya suatu tahap perlu diulang kembali sebelum tahap berikutnya dilanjutkan. (Sarwono, J. \& Lubis, H., 2007). Ada 8 tahapan yang harus dilalui dalam metode ini. Tahap awal yaitu brief, menganalisis permasalahan yang ada sambil memantapkan ide yang telah dimiliki peneliti. Kemudian peneliti mulai mengajukan judul yang telah dimantapkan kepada Ketua Jurusan Pendidikan Teknik Informatika. Setelah judul disetujui, makan tahap selanjutnya adalah pengumpulan data dan analisis kebutuhan dengan terjun langsung kelapangan dan bertemu narasumber. Setelah semua informasi terkumpul, lalu seluruh analisis sesuai dengan yang ada di metode dilakukan.

Setelah data-data yang diperlukan terkumpul dan lengkap, peneliti melanjutkan dengan membuat synopsis, scenario dan juga storyboard yang digunakan sebagai acuan saat pengambilang gambar. Peneliti mulai merancang dan merencanakan bagaimana proses pembuatan film akan berlangsung. Tahap selanjutnya yaitu Evaluasi 1.

Evaluasi tahap 1, pada tahap ini dilakukan uji ahli isi dan media untuk praproduksi sebagai penentu layak atau tidaknya sebuah film mulai dikerjakan. Uji ahli isi dilakukan oleh 2 orang, yaitu Anak Agung Ngurah Brawida dan juga Anak Ngurah Sentanu. Sedangkan uji ahli media dilakukan oleh Putu Satria Kusuma dan Kardian Narayana. Setelah dilakukan pengujian diperoleh hasil rata-rata persentase penilaian yaitu sebesar $100 \%$, sehingga dapat dikatakan layak untuk dilanjutkan ke tahap produksi.

Pada tahap produksi peneliti mulai melakukan proses pengambilan gambar yang dibantu dengan crew di lokasi-lokasi dan dengan actor yang telah ditentukan. Setelah proses pengambilan gambar selesai kemudian dilakukan tahapan pasca produksi. Di mana dalam tahapan ini terdiri dari proses editing dan rendering.

Setelah tahap 3 selesai, maka dilanjutkan evaluasi 2. Evaluasi 2 dilakukan untuk menguji Film Dokumenter Anak Agung Pandji Tisna "Jejak Pujangga Pionir Lovina" yang telah selesai dibuat. Uji ahli isi dilakukan dengan instrumen angket dan melibatkan 2 ahli yaitu Anak Agung Ngurah Brawida dan Anak Agung Ngurah Sentanu, diperoleh hasil rata-rata persentase penilaian yaitu sebesar $100 \%$, sehingga sudah sesuai dengan rancangan yang dibuat dan fakta yang sebenarnya. Sedangkan untuk uji ahli media dilakukan dengan instrumen angket dan melibatkan 2 ahli diperoleh hasil rata-rata persentase penilaian yaitu sebesar $88,89 \%$, sehingga dapat dikatakan memenuhi penilaian dari ahli media dan dapat dipublikasikan. Namun terdapat beberapa kendala yang menyebabkan hasil kurang maksimal yaitu pemilihan jenis shot kurang bervariasi, kurangnya peralatan sehingga menyebabkan kualitas audio tidak jernih dan kurang stabilnya kamera yang menyebabkan beberapa hasil shoot goyang.

Pada tahap 4 dilakukan proses burning file yang sudah di-render, kemudian dikemas dalam bentuk DVD dan dapat dipublikasikan. Dilanjutkan ke tahap outcome yang merupakan tahap terakhir pada pembuatan Film Dokumenter Anak Agung Pandji Tisna "Jejak Pujangga Pionir Lovina". Tahapan outcome ini adalah mempublikasian Film Dokumenter Anak Agung Pandji Tisna "Jejak Pujangga Pionir Lovina" dalam bentuk DVD yang telah dibuat dan dipromosikan dengan media poster.

Setelah semua tahap dilalui, maka akan dilakukan uji respon penonton untuk mengetahui respon dari penonton setelah menonton film. Pengujian ini menggunakan 
angket skala lima dengan melibatkan 30 responden yang dipilih secara acak, diperoleh hasil rata-rata persentase penilaian yang didapat yaitu sebesar 91,2 $\%$ masuk dalam kategori Sangat Baik. Berdasarkan butir-butir pernyataan angket uji respon penonton tersebut dapat dinyatakan bahwa Film dokumenter Anak Agung Pandji Tisna "Jejak Pujangga Pionir Lovina" layak menjadi media publikasi untuk pelestarian wisata dan memperkenalkan sosok yang berjasa dan bersejarah yakni Anak Agung Pandji Tisna. Hal ini sejalan dengan hasil penelitian Film Dokumenter Anjing Bali Tuan Rumah Sejuta Kisah yang juga layak dipublikasikan sebagai media untuk melestarikan anjing Bali yang hampir punah (Sitangga Putra, Darmawiguna, \& Pradnyana , 2017).

Film Dokumenter Anak Agung Pandji Tisna "Jejak Pujangga Pionir Lovina" mengupas sejarah Anak Agung Pandji Tisna dalam dedikasinya menciptakan tempat pariwisata. Stimulus gagasan konsep yang dikembangkan Pandji Tisna tersebut mendorong berkembangnya bisnis perhotelan di Buleleng Timur dan Buleleng Barat. Mulai tahun 1970-an, kalangan investor tertarik untuk membangun akomodasi (hotel, homestay, dan villa) di areal sekitar Guest House milik beliau, yakni "Lovina".

Film ini dibuat dengan maksud mengenalkan konsep pariwisata yang telah dibangun melalui Lovina pada tahun 1953 yang saat ini mulai terlupakan oleh masyarakat Buleleng, mengungkapkan secara jelas fakta-fakta tentang Lovina dimulai dari letak kawasan Lovina hingga arti kata Lovina yang sebenarnya. Film ini juga bertujuan untuk mengembalikan Anak Agung Pandji Tisna ke dalam hati masyarakat Buleleng sebagai sosok yang telah meninggalkan karya-karyanya untuk dilestarikan dan dikembangkan. Pembuatan film dokumenter semacam ini memberikan pembelajaran yang sangat dalam untuk menghargai jasa - jasa para tokoh di masa lampau. Tidak hanya bagi penonton, namun juga bagi pembuat film dokumenter tersebut.
Pembuatan Film Dokumenter Anak Agung Pandji Tisna "Jejak Pujangga Pionir Lovina" tidak lepas dari berbagai kendala. Adapun kendala-kendala yang dihadapi salah satunya yaitu kendala lain yaitu menentukkan jadwal untuk pengambilan gambar wawancara dengan narasumber, dimana beberapa narasumber memiliki kesibukkan yang berbeda, namun kendala tersebut dapat teratasi dengan menjalin komunikasi yang baik dengan narasumber sehingga jadwal pengambilan gambar bisa dikoordinasikan dengan baik. Kendala lain seperti audio yang sedikit noise, karena keterbatasan alat dan tempat yang digunakan terdapat beberapa sumber suara lain.

Film Dokumenter Anak Agung Pandji Tisna "Jejak Pujangga Pionir Lovina" tentunya masih memiliki banyak kekurangan, baik dalam hal teknis maupun non teknis. Dibalik kekurangan tersebut, film dokumenter ini juga memiliki kelebihan yaitu film ini memiliki alur cerita yang mengangkat biografi Anak Agung Pandji Tisna serta salah satu karyanya yang populer dan sejarahnya.

\section{SIMPULAN}

Berdasarkan hasil penelitian dan pembahasan Film Dokumenter Anak Agung Pandji Tisna "Jejak Pujangga Pionir Lovina", maka penulis dapat menarik kesimpulan sebagai berikut:

Implementasi Film Dokumenter Anak Agung Pandji Tisna "Jejak Pujangga Pionir Lovina" telah berhasil dilakukan dengan menggunakan motode cyclic strategy dan tahapan pra produksi, produksi dan pasca produksi. Film Dokumenter Anak Agung Pandji Tisna "Jejak Pujangga Pionir Lovina" merupakan sebuah media publikasi yang dapat digunakan untuk memperkenalkan dan mendokumentasikan Anak Agung Pandji Tisna dan sejarah Lovina agar tidak mudah dilupakan oleh kalangan masyarakat terutama generasi muda. Informasi yang terdapat dalam film ini berdasarkan hasil dari wawancara dengan dua orang narasumber yang mengetahui tentang Anak Agung Pandji Tisna dan juga Lovina. Sebelum dipublikasikan film ini 
sudah diujikan kepada dua orang ahli isi dan dua orang ahli media menggunakan instrumen angket. Berdasarkan uji ahli isi diperoleh presentase $100 \%$ dan uji ahli media diperoleh persentase sebesar 88,89 $\%$.

Berdasarkan hasil uji respon penonton Film Dokumenter Anak Agung Pandji Tisna "Jejak Pujangga Pionir Lovina" yang melibatkan 30 responden diambil secara acak memperoleh persentase sebesar 91,2 $\%$. Hasil yang diperoleh ini dikategorikan ke dalam pencapaian sangat baik. Jadi informasi yang terdapat pada Film Dokumenter Anak Agung Pandji Tisna "Jejak Pujangga Pionir Lovina" telah tersampaikan dengan sangat baik.

\section{SARAN}

Saran bagi para penliti yang akan meneliti film dokumenter selanjutnya antara lain:

a. Peneliti selanjutnya disarankan untuk menyusun lebih dari satu rencana saat pengambilan gambar karena situasi dan kondisi dilapangan tidak dapat diperkirakan.

b. Peneliti selanjutnya disarankan untuk memperdalam dan mempelajari hal-hal yang lebih baru yang muncul dalam perfilman, agar dapat berkreasi lebih luas.

c. Film dokumenter ini dapat digunakan sebagai acuan dalam penelitian yang berkaitan dengan pengembangan film dokumenter ataupun penelitian eksperimen untuk film dokumenter.

\section{REFERENSI}

[1] I. G. N. Gorda, Biografi Anak Agung Pandji Tisna Raja Buleleng, Budayawan, Pendidik dan Pelopor Pariwisata, Denpasar: Astabrata Bali, 2006.

[2] M. A. Ole, "Mengenang Pandji Tisna Pujangga Besar yang Sepi Peringatan," 1102 2017. [Online]. Available: http://tatkala.co/2017/02/11/mengenangpandji-tisna-pujangga-besar-yang-sepi- dari-upacara-peringatan/.

[3] H. Pratista, Memahami Film, Yogyakarta: Homerian Pustaka, 2008.

[4] I. D. G. A. Sitangga Putra, I. G. M. Darmawiguna dan G. A. Pradnyana , "Film Dokumenter Anjing Bali Tuan Rumah, Sejuta Kisah," KARMAPATI, p. Volume 6 Nomor 1, 2017.

[5] I. G. J. Permana Bayu, G. S. Santyadiputra dan I. M. A. Pradnyana, "Film Dokumenter Permainan Tradisional Bali "Magandu" : Sebuah Tradisi Sebagai Warisan Budaya Sistem Subak Bali," KARMAPATI, p. Volume 6 Nomor 1, 2017.

[6] J. Sarwono dan H. Lubis, Metode Riset untuk Desain Komunikasi Visual, Yogyakarta: Andi, 2007, p. Andi. 